\title{
The Interplay Between Emotional Intelligence, Oral Communication Skills and Second Language Speaking Anxiety: A Structural Equation Modeling Approach
}

\author{
ALI ALGHORBANY \\ School of Languages, Civilisation and Philosophy, \\ Universiti Utara Malaysia \\ MOHD HILMI HAMZAH (Corresponding Author) \\ School of Languages, Civilisation and Philosophy, \\ Universiti Utara Malaysia \\ hilmihamzah@uum.edu.my
}

\begin{abstract}
The study aimed at identifying the association between Goleman's emotional intelligence and second language speaking anxiety by employing oral communication skills as the mediating variable. A correlational research design was used. A total of 209 first and second-year Malaysian undergraduate ESL students were selected from one public university in Malaysia. The study employed the proportionate stratified random sampling. In order to collect data, three questionnaires including 'Emotional Competence Inventory (ECI)', 'Foreign Language Classroom Anxiety Scale (FLCAS)', and 'Oral Communication Skills Scale' were used. Testing the hypotheses required correlational analysis done via Smart PLS 3.0. Results provided support for the proposed conceptual framework, disclosing that emotional intelligence was significantly associated with oral communication skills. Also, oral communication skills were significantly associated with second language speaking anxiety. Lastly, oral communication skills mediated the association between emotional intelligence and second language speaking anxiety. The current study offered ESL students, educator and policymakers several theoretical and practical implications.
\end{abstract}

Keywords: Emotional intelligence; second language speaking anxiety; oral communication skills; structural equation modeling; Malaysian ESL students

\section{INTRODUCTION}

Language learning in the academic setting is believed to vary based on mastering language skills which are prone to deteriorate due to several psychological factors, particularly, second language anxiety (Cheng, 2017; Dewaele, MacIntyre, Boudreau, \& Dewaele, 2016; Horwitz, 2016; Horwitz, Horwitz \& Cope, 1986; Hwang, Hsu, Lai, \& Hsueh, 2017; MacIntyre \& Gardner, 1988; Teimouri, Goetze, \& Plonsky, 2019; Young, 1991, 1992). Regrettably, language anxiety is believed to cause academic failure in English as second language (ESL) countries, including Malaysia (Miskam \& Saidalvi, 2019). More precisely, speaking skill is the dominant source of language anxiety among the other three skills i.e., reading, writing and listening (Horwitz et al., 1986; MacIntyre \& Gardner, 1988; Cheng, 2017). In Malaysia, the majority of Malaysian undergraduates "have a serious lacking in speaking English and this situation has raised an alarming concern in securing employment in the future" (Miskam \& Saidalvi, 2019, p. 1). Similarly, in the context of Malaysia, researchers revealed that Malaysian students encounter serious learning hurdles due to language anxiety (Azarfam \& Baki, 2012; Hamzah, 2007; Zhiping \& Paramasivam, 2013).

Research indicates that students speak confidently if they practice a sufficient amount of oral skills through oral interactions in their classrooms (Lee, 2016; Melchor-Couto, 2017; Villalba \& Luz, 2017). It has been established in 'social cognitive theory' (SCT) that an individual's environment relatively affects their own behaviour which play a significant role in their achievements or failures (Bandura 1986). Oral communication skills are significantly 
and negatively associated with foreign language anxiety level (Amengual-Pizarro, 2018). In fact, a major "key educational concern in Malaysia is the pupils' limited communicative skills in English" (Meganathan, Yap, Paramasivam, \& Jalaluddin, 2019, p., 55). In terms of oral communication skills, second language speaking anxiety needs attention in Malaysia. In the context of Malaysia, only few researchers have conducted studies to investigate the relationship between certain kinds of language anxiety (i.e., reading language anxiety, writing language anxiety, listening language anxiety) and different kinds of achievements (i.e., academic achievement, language achievement) (Daud, Daud, \& Kassim, 2016; Dewaele, Witney, Saito, \& Dewaele, 2018; Guvenc et al., 2016; Khawaja, Chan, \& Stein, 2017; Marwan, 2016; Rajab, Zakaria, Rahman, Hosni, \& Hassani, 2012; Serraj \& Noordin, 2013; Thompson \& Khawaja, 2016). However, there is a severe dearth of studies related to 'second language speaking anxiety'.

Furthermore, the SCT by Bandura (1986) affirmed that person's traits and cognitive abilities (e.g., emotional intelligence) reciprocally affect, and get affected by, environment and behaviour (refer to Figure 1). Emotional intelligence (EI), based on its originator Daniel Goleman consists of five constructs. While the first construct, i.e., self-awareness, refers to awareness of emotions intrapersonally and self-confidence, the second, self-regulation implies emotional self-control, adaptability and eagerness (Giorgi \& Majer, 2009). The next construct, i.e., motivation, is defined as "an inner source, desire, emotion, reason, need, impulse or purpose that moves a person to a particular action" (Chalak \& Kassaian, 2010). Motivation is seen as the primary variable that affects language learning (Cohen \& Dornyei, 2002; Ilter, 2009; Tsao, Tseng, \& Wang, 2017). Empathy, the fourth construct, entails organisational awareness and service orientation (Goleman, Boyatzis, \& McKee, 2002; Giorgi, 2013; Giorgi $\&$ Majer, 2009). The last construct is social skills which encompass the power of collaboration and teamwork (Boyatzis, Goleman, \& Rhee, 2000; Boyatzis \& Saatcioglu, 2008). These five modelled constructs of EI as a set of acquired competencies are responsible for developing behaviour and performance (Goleman, 1998). In the previous literature, researchers found relationships between EI and various academic variables including academic achievement, mathematics, management, English language achievement, and French language achievement (Festus, 2012; McCleskey, 2014; Colomeischi \& Colomeischi, 2015; Musonda, 2017; Tariq, Qualter, Roberts, Appleby, \& Barnes, 2013; Yeigh et al., 2016). However, there is scarcity of research related to the relationship between EI and second language speaking anxiety. For that reason, this study aimed to establish the role of 'EI' in 'second language speaking anxiety' by using 'oral communication skills' as a mediating variable. The next section presents the research objectives of the current study.

\section{RESEARCH OBJECTIVES}

This research intends to attain the following objectives:

1- To examine the relationship between Malaysian undergraduate ESL students' EI level and their oral communication skills

2- To examine the relationship between Malaysian undergraduate ESL students' oral communication skills and their second language speaking anxiety

3- To determine the mediating role of oral communication skills between EI and second language speaking anxiety among Malaysian undergraduate ESL students 


\section{CONCEPTUAL AND THEORETICAL FRAMEWORKS}

The conceptual framework of the current study is shown below in Figure 1. As evident from Figure 1, this study consisted of one independent variable, i.e., EI. Moreover, 'oral communication skills' acted as a mediating variable. Lastly, 'second language speaking anxiety' was the dependent variable.

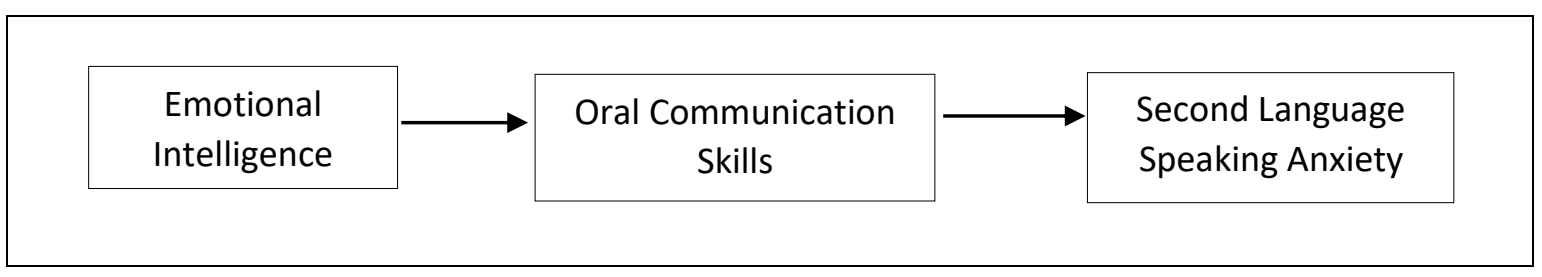

FIGURE 1. Conceptual Framework

As already explained in the previous section, there is no direct association between EI and second language speaking anxiety in the past literature. However, after reviewing the literature, it was established that there was a substantial association between EI and oral communication skills (Engelberg \& Sjöberg, 2005; Chang \& Hu, 2017; Marzuki, Mustaffa, \& Saad, 2015; Schutte, Malouff, Simunek, McKenley, \& Hollander, 2002; Suhaimi, Marzuki \& Mustaffa, 2014) and also between oral communication skills and second language speaking anxiety (Ahmed, Pathan, \& Khan, 2017; Akbar, Sofyan, \& Damayanti, 2018; Alias, Sidhu \& Fook, 2013; AY, 2010; Çağatay, 2015; Debreli \& Demirkan, 2015; Doğan \& Tuncer, 2016; El-Sakka, 2016; Gaibani \& Elmenfi, 2016; Haskin, Smith \& Racine, 2003; Lee, 2016; MacIntyre \& Gardner, 1991; Price, 1991; Razak, Yassin, \& Maasum, 2017; Soomro et al., 2019; Young, 1991, 1992). According to Preacher, Rucker and Hayes (2007), mediation (M) takes place when the causal effect of an independent variable $(\mathrm{X})$ on a dependent variable $(\mathrm{Y})$ is transferred by a mediating variable (M). In simpler terms, if $\mathrm{M}$ is influenced by $\mathrm{X}$ and $\mathrm{Y}$ is influenced by $\mathrm{M}$, then in turn, $\mathrm{Y}$ is influenced by $\mathrm{X}$. Thus, oral communication skills were employed as a mediator between EI and second language speaking anxiety. In addition, based on our observation in the literature, oral communication skills were hardly used as a mediating variable between EI and second language speaking anxiety. Thus, oral communication skills was used as a mediator in the current study.

In light of the above-mentioned studies and identified theoretical gaps in the present research, the theoretical framework was created. The theoretical framework is illustrated in Figure 2 below. This study employs Social Cognitive Theory (SCT) by Bandura $(1986,1997)$ as the theoretical framework upon which the variables are correlated. SCT is widely known for its focus on reciprocity of three aspects, i.e., personal trait, environmental stimuli and behaviour (Bandura, 2001; Herz, Schunk \& Zehnder, 2014). Bandura (1986, 2001) demonstrates this reciprocity as 'reciprocal determinism'. Generally, the three aspects of SCT are responsible to cover the three variables of the present study. That is to say, the first aspect, personal trait, pertains to several cognitive abilities like EI (Bandura, 1986). In addition, personal traits directly include components of EI such as stress management and self-regulation. Secondly, environment and its stimuli refer to all personal and interpersonal interactions (Bandura, 2001; Herz et al., 2014; Shehzad, Lashari, Alghorbany, \& Lashari, 2019) within an environment such as oral communication skills. Oral communication skills and their construct of motivation are components of the environment (Dörnyei \& Ushioda, 2011; Hamat, \& Hassan, 2019). Lastly, behaviour, the third aspect of SCT, covers anxiety as it is a 'negative behaviour' (Gardner, 1994). Thus, the model of triadic reciprocity proposed in this study explains the correlational 
nature of the research variables (i.e., EI, oral communication skills, and second language speaking anxiety).

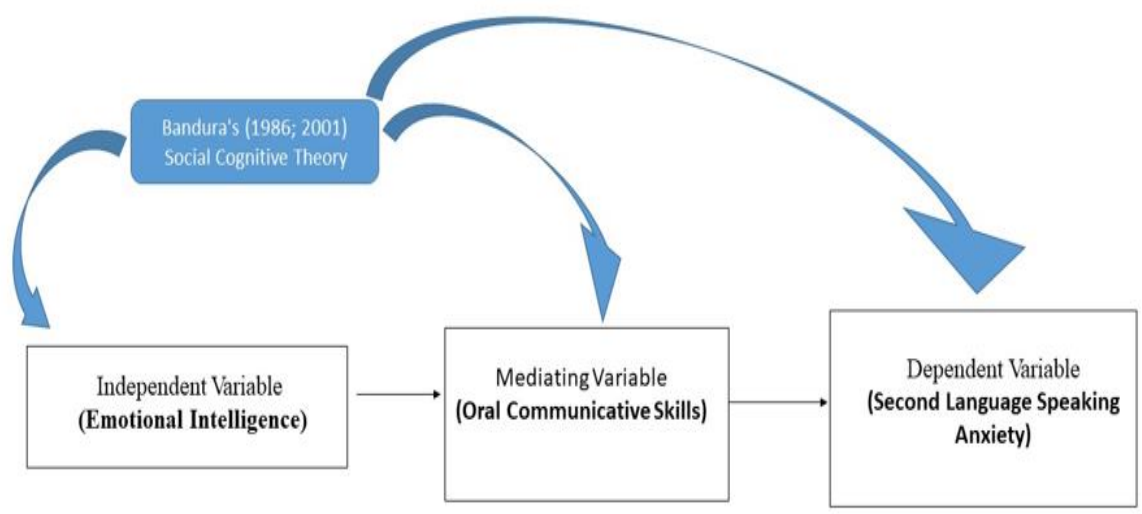

FIGURE 2. Theoretical Framework

\section{LITERATURE REVIEW}

\section{EI AND ORAL COMMUNICATION SKILLS}

The previous studies determined the connection between EI and oral communication skills in various fields. For instance, several researchers determined the relationship between two variables in the academic fields of business, English language and science (Afshar, \& Rahimi, 2014; 2016; Chang \& Hu, 2017; Ebrahimi, Khoshsima, Zare-Behtash, \& Heydarnejad, 2018; Fall, Kelly, MacDonald, Primm, \& Holmes, 2013; Schutte et al., 2002). All of these studies revealed a substantial connection between EI and oral communication skills. Additionally, few researchers conducted studies regarding the association between these two variables in the professional settings of management and health care (Batool, 2013; Erigüç \& Köse, 2013; Lee $\& \mathrm{Gu}, 2013$ ). All of the aforementioned studies concluded that there exists a significant connection between EI and oral communication skills. Interestingly, researchers found that both EI and oral communication skills significantly improved the effectiveness of disaster management in Malaysia (Suhaimi et al., 2014). Another recent study concluded that EI is significantly associated with communication competence and also moderates the correlation between communication competence and self-efficacy (Chang \& $\mathrm{Hu}, 2017$ ).

Based on the review of the above studies, it is worth mentioning that the majority of the studies focused on the academic setting in universities. Also, Chang and $\mathrm{Hu}$ (2017) suggested for future researchers that research ought to be conducted to find other associations between the two variables. We considered the recommendations given by the above-mentioned researchers and consequently examined the connection between EI and oral communication skills.

The current section has reviewed the studies related to EI with various academic variables. The next section reviews the studies regarding the association between oral communication skills and second language speaking anxiety.

\section{ORAL COMMUNICATION SKILLS AND SECOND LANGUAGE SPEAKING ANXIETY}

Several studies were conducted to examine the interplay between communication skills and second language anxiety. Alias et al. (2013) revealed that communication skills are connected 
to the construct of foreign language classroom anxiety, i.e., 'communication apprehension'. However, the majority of the researchers employed qualitative designs using interviews to investigate such phenomena (Afshar \& Rahimi, 2014; Alias et al., 2013; Azarfam \& Baki, 2012; Ohata, 2005; Pappamihiel, 2002; Soomro et al., 2019; Zhiping \& Paramasivam, 2013).

Notably, the researchers who examined the association between communication skills and second language speaking anxiety differ in the nature of the sample of their studies. A few researchers chose primary school students as their samples (Alshahrani \& Alandal, 2015; Nijat, Atifnigar, Chandran, Selvan, \& Subramonie, 2019). Moreover, several studies were conducted on high-school students (Khoshsima, Sarani, \& Ganji, 2018; Liu \& Chen, 2015; Maisarah, 2019; Mukminin, Masbirorotni, Noprival, Sutarno, Arif, \& Maimunah, 2015; Tercan \& Dikilitaş, 2015; Santos, Gorter, \& Cenoz, 2017). Lastly, various studies were conducted in university settings (Ahmed, Pathan, \& Khan, 2017; Akbar, Sofyan, \& Damayanti, 2018; Çağatay, 2015; Debreli \& Demirkan, 2015; Doğan \& Tuncer, 2016; El-Sakka, 2016; Gaibani \& Elmenfi, 2016; Razak, Yassin, \& Maasum, 2017). All of the previous studies found a significant association between oral communication skills and second language speaking anxiety. For instance, Ahmed et al. (2017) investigated the factor that led to second language speaking anxiety among 240 postgraduate students in a Pakistani university. The study was quantitative in nature using SPSS to analyse the data. The results of their study showed that the students feel anxious to speak to others in a classroom due to the lack of communication skills. Similarly, a study was conducted by Akbar et al. (2018) on the causes of foreign language speaking anxiety among 79 third-semester students in Indonesia; they reported that the students were mildly anxious to talk to each other in English due to a lack of communication skills. Another study by Çağatay (2015) examined EFL university students' foreign language speaking anxiety in Turkey. After collecting the data via questionnaires from 147 Turkish students at the English preparatory programme, findings showed significant associations among foreign language speaking anxiety, oral communicative skills, and gender.

\section{METHODOLOGY}

\section{RESEARCH DESIGN}

A quantitative research design was used in the present study due to its nature and objectives. Furthermore, in accordance with the research objectives, a correlational research design was implemented.

\section{SAMPLING}

A population is a group of entities that have same attributes that differentiate them from other groups (Creswell, 2003). Therefore, the population of the present study was male and female Malaysian undergraduate ESL students studying in a public university, i.e., Universiti Utara Malaysia (UUM). The university of UUM has three colleges, i.e., College of Arts and Sciences (CAS), College of Business (COB) and College of Law, Government and International Studies (COLGIS). In order to collect the data from the students of the aforementioned three colleges, a proportionate stratified random sampling was employed. Furthermore, a certain proportion of sample was selected from each of the three colleges (stratas) based on their respective population. For instance, the sample proportion of 'COB' was the highest due to the reason that it had the highest population as compared to the other colleges (refer to Table 1). 
TABLE 1. Proportion of Quantitative Sample

\begin{tabular}{llccc}
\hline No. & \multicolumn{1}{c}{ Name of College } & Population & Percentage & $\begin{array}{c}\text { Sample } \\
\text { (students) }\end{array}$ \\
\hline 1 & College of Business & 9117 & $57 \%$ & 119 \\
2 & College of Law, Government and International Studies & 3472 & $22 \%$ & 46 \\
3 & College of Arts and Sciences & 3376 & $21 \%$ & 44 \\
& TOTAL & 15965 & $100 \%$ & 209 \\
\hline
\end{tabular}

Regarding sample size, the present study followed the table of sampling presented by Bartlett, Kotrlik and Higgins (2001). The sampling table indicates that, for the population above 10000 subjects, the appropriate sample is 209 . Thus, the sample of the current study was 209 Malaysian undergraduate ESL students.

\section{INSTRUMENTS}

In order to test the relationship among EI, oral communication skills and second language speaking anxiety, three self-administered questionnaires were used. Firstly, 'Emotional Competence Inventory (ECI)' was adapted from Goleman (1998) for measuring the independent variable, i.e., EI. It consists of 40 items that tackle the five dimensions of EI (i.e., self-awareness, self-regulation, motivation, empathy, social skill). More particularly, selfawareness was assessed by five items, self-regulation was measured by nine items, motivation was assessed by seven items, empathy was assessed with nine items, and social skill was assessed with ten items.

Secondly, with the aim of collecting data regarding oral communication skills, a scale adapted from Morreale, Spitzberg and Barge (2007) was employed. It originally was a fourpoint scale but it was adapted to a five-point Likert scale (' 1 ' refers to minimal competence whereas ' 5 ' refers to high competence) to match with the other two questionnaires and for statistical purposes. Also, the scale contained 21 items. However, one item was omitted due to its inappropriateness to the Malaysian culture (i.e., Item 5: Discussing safe sex with someone you are considering sexual relations with). This instrument was found rigorous in measuring the level of students' communication skills (Chang \& Hu, 2017; Marzuki et al., 2015).

Lastly, Foreign Language Classroom Anxiety Scale (FLCAS) was distributed in order to gather data regarding second language speaking anxiety (i.e., dependent variable). FLCAS was adapted from Horwitz et al. (1986). The aforementioned scale contains 33 items and employs a five-point Likert scale with a textual response format ranging from 'Strongly agree', 'Agree', 'Not sure', 'Disagree', to 'Strongly disagree'. Although the scale is titled 'Foreign Language Classroom Anxiety Scale', there are three main reasons that justify adapting it in the Malaysian ESL context. Firstly, the authors of FLCAS stated that their model and scale seek to investigate issues "concerning anxiety and second language achievement" (Horwitz et al., 1986, p. 126). Also, in their model, they use the words L2 and FL interchangeably which makes it clear that this scale is meant for both ESL and EFL contexts. Thirdly, many studies have used FLCAS in ESL contexts (e.g., Aida, 1994) and especially in Malaysia (e.g., Al-Saqqaf, 2015; Lian \& Budin, 2014; Heng, Abdullah, \& Yusof, 2012). Therefore, FLCAS fits well in the ESL Malaysian context.

\section{STATISTICAL ANALYSES AND RESULTS}

The two-phase method (i.e., 'structural model assessment' and 'measurement model assessment') by Henseler, Ringle, and Sinkovics (2009) was seen to best present PLS-SEM 
results (Hair, Ringle, \& Sarstedt, 2013). The two phases' components are listed by Hameed et al. (2018) as illustrated in Figure 2.

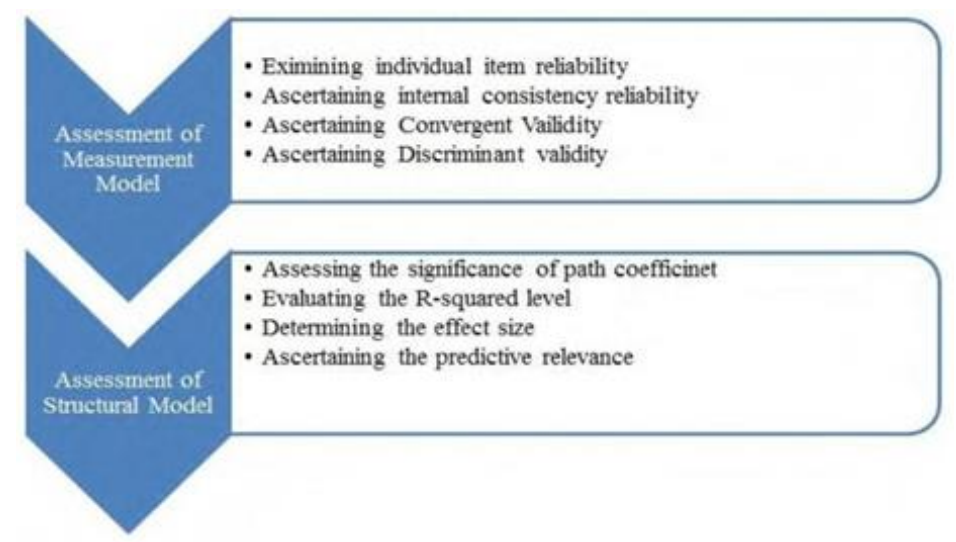

FIGURE 2. Two-Step PLS-SEM (Hameed et al, 2018)

\section{MEASUREMENT MODEL}

The measurement model assessment necessitates scrutinising various entities including Cronbach's alpha, composite reliability (CR), factor loadings, discriminant validity, and average variance extracted (AVE). The outcomes of this model are shown in Figure 3 and Table 2. Also, the factor loadings of all variables are shown in Figure 3. It is worth mentioning that the value of factor loadings must be higher than 0.5 for the sake of establishing convergent validity (Hair Black, Babin, Andersen, \& Tatham, 2010). All factor loading values of the present study's variables are fulfilled. More precisely, the values range from 0.50 to 0.90 . Thus, convergent validity is established. 


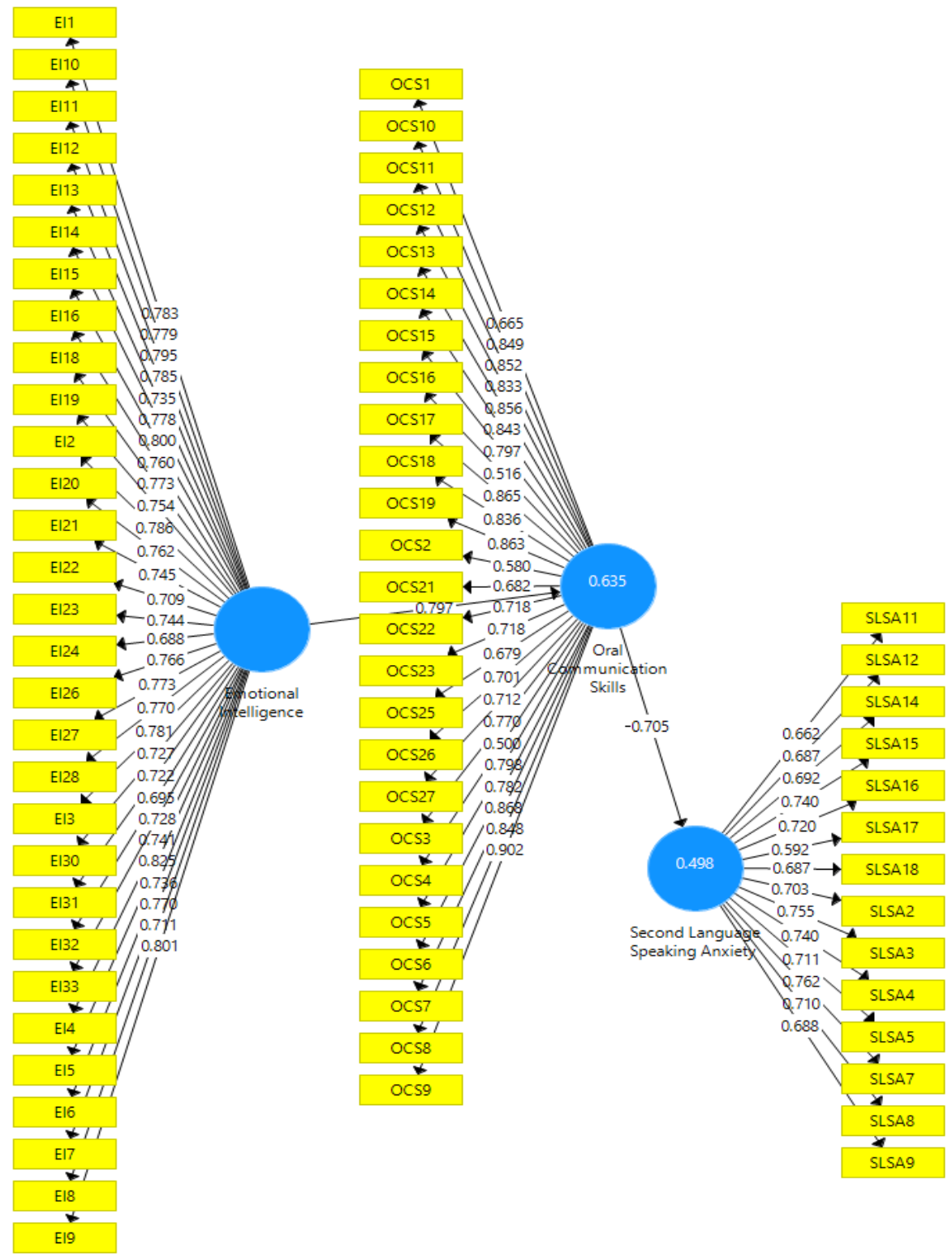

FIGURE 3. Confirmatory factor analysis

This study's values of Cronbach's alpha, CR, and AVE are listed in Table 1. Concerning the norm of Cronbach's alpha value, it must be higher than 0.7 (George \& Mallery, 2016). The Cronbach's alpha value of the present study ranges from 0.927 to 0.974 . In addition, concerning CR standard, it must be $(\geq 0.7)$ and the value of AVE must be $(\geq 0.5)$ (Fornell \& Larcker, 1981). In the present study, the norms of CR and AVE are attained (refer to Table 2). Moreover, discriminant validity is attained via Heterotrait-Monotrait Ratio (HTMT) method (refer to Table 2).

TABLE 2. Cronbach's Alpha, composite reliability and AVE

\begin{tabular}{lcccc}
\hline & Cronbach's & & & $\begin{array}{c}\text { Average } \\
\text { Variance } \\
\text { Extracted } \\
\text { (AVE) }\end{array}$ \\
\hline Emotional Intelligence & 0.974 & 0.975 & 0.976 & 0.575 \\
Oral Communication Skills & 0.970 & 0.973 & 0.973 & 0.592 \\
Second Language Speaking Anxiety & 0.927 & 0.941 & 0.932 & 0.5 \\
\hline
\end{tabular}




\section{STRUCTURAL MODEL}

The structural model was assessed for the sake of determining the influence of EI on oral communication skills and second language speaking anxiety. Also, for accepting or rejecting the hypotheses, $\mathrm{t}$-values and path coefficient values were calculated.

TABLE 3. Heterotrait-Monotrait Ratio (HTMT)

\begin{tabular}{lcc}
\hline & Emotional Intelligence & Oral Communication Skills \\
\hline Emotional Intelligence & & \\
Oral Communication Skills & 0.809 & \\
Second Language Speaking Anxiety & 0.598 & 0.658 \\
\hline
\end{tabular}

Furthermore, effect size $\left(f^{2}\right)$ and R-Square $\left(R^{2}\right)$ were determined through employing the structural model. The $\mathrm{t}$-values of all the three hypotheses were greater than 1.96 , therefore, all the three hypotheses were accepted. In other words, EI was significantly correlated with second language speaking anxiety. Additionally, the effect size $\left(f^{2}\right)$ is demonstrated in Table 6 . According to Cohen (1988), the effect size value of (0.2) is considered small, (0.5) represents a 'medium' effect size, and ( $\geq 0.8)$ is a 'large' effect size. In the current study, EI has a medium effect size and second language speaking anxiety has a large one (refer to Table 6).

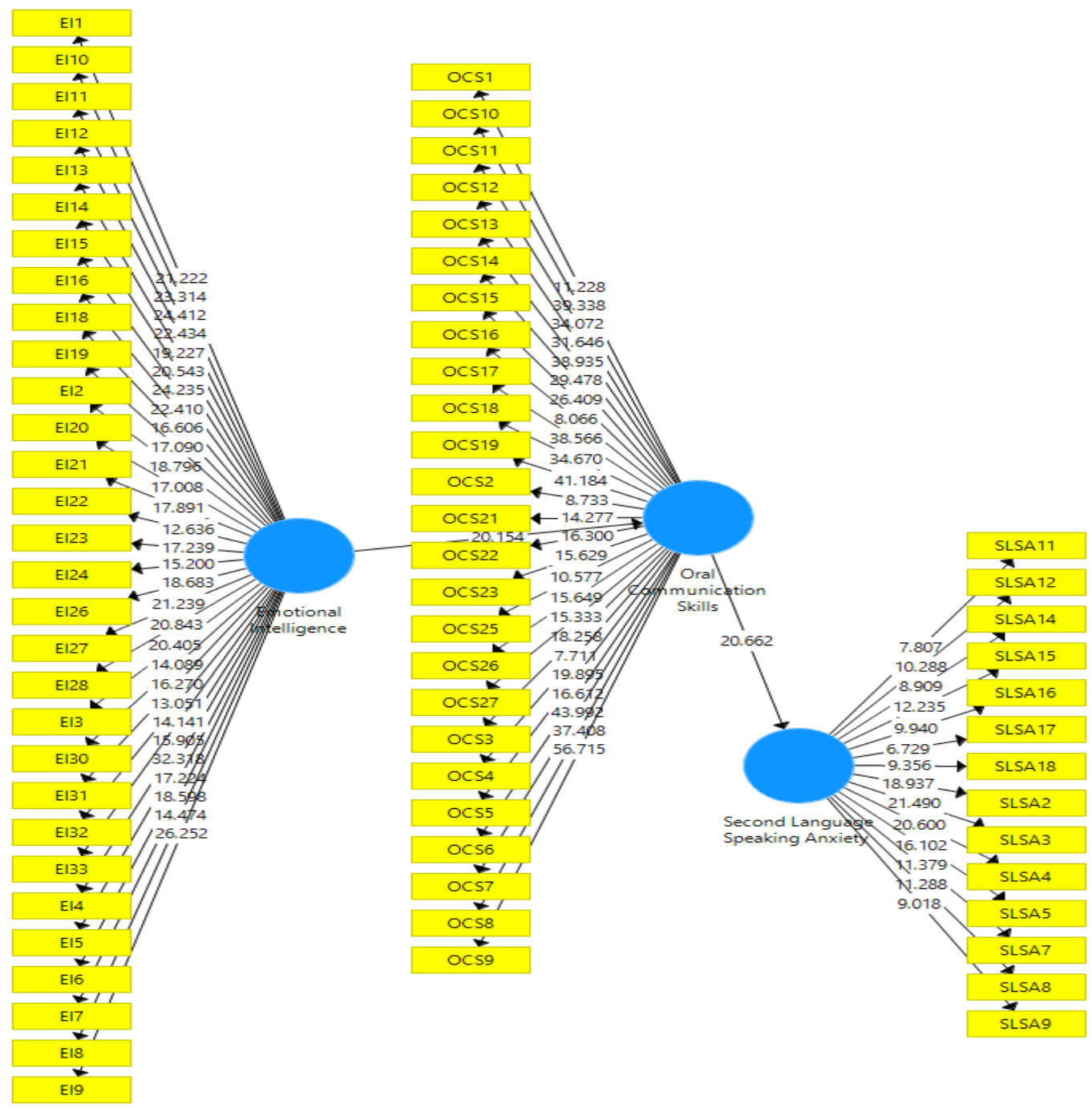

FIGURE 4. Structural model assessment 
TABLE 4. Structural model assessment (Direct relationship)

\begin{tabular}{lccccc}
\hline & $\begin{array}{c}\text { Original } \\
\text { Sample (O) }\end{array}$ & $\begin{array}{c}\text { Sample } \\
\text { Mean (M) }\end{array}$ & $\begin{array}{c}\text { Standard } \\
\text { Deviation } \\
(\text { STDEV })\end{array}$ & $\begin{array}{c}\text { T Statistics } \\
(|\mathrm{O} / \mathrm{STDEV}|)\end{array}$ & P Values \\
\hline $\begin{array}{l}\text { Emotional Intelligence -> Oral Communication } \\
\text { Skills }\end{array}$ & 0.797 & 0.799 & 0.04 & 20.154 & 0 \\
& & & & & \\
$\begin{array}{l}\text { Oral Communication Skills -> Second } \\
\text { Language Speaking Anxiety }\end{array}$ & -0.705 & -0.715 & 0.034 & 20.662 & 0 \\
\hline
\end{tabular}

TABLE 5. Structural model assessment (Indirect relationship)

\begin{tabular}{|c|c|c|c|c|c|}
\hline & $\begin{array}{c}\text { Original } \\
\text { Sample (O) }\end{array}$ & $\begin{array}{l}\text { Sample Mean } \\
\text { (M) }\end{array}$ & $\begin{array}{c}\text { Standard } \\
\text { Deviation } \\
\text { (STDEV) }\end{array}$ & $\begin{array}{l}\text { T Statistics } \\
(|\mathrm{O} / \mathrm{STDEV}|)\end{array}$ & P Values \\
\hline $\begin{array}{l}\text { Emotional Intelligence -> Oral Communication } \\
\text { Skills -> Second Language Speaking Anxiety }\end{array}$ & 0.562 & 0.572 & 0.046 & 12.128 & 0.000 \\
\hline
\end{tabular}

TABLE 6. Effect Size $\left(f^{2}\right)$

\begin{tabular}{lcc}
\hline & Oral Communication Skills & $\begin{array}{c}\text { Second Language } \\
\text { Speaking Anxiety }\end{array}$ \\
\hline Emotional Intelligence & 0.741 & \\
Oral Communication Skills & & 0.99 \\
\hline
\end{tabular}

The $R^{2}$ values are shown in Table 7. They indicate that EI impacted oral communication skills by $63 \%$, and foreign language speaking anxiety by $50 \%$.

TABLE 7. $R$-Square $\left(R^{2}\right)$ Value

\begin{tabular}{lc}
\hline & R Square \\
\hline Oral Communication Skills & 0.635 \\
Second Language Speaking Anxiety & 0.499 \\
\hline
\end{tabular}

\section{DISCUSSION}

The finding of the first research objective indicated that EI was significantly and positively associated with oral communication skills. The present study's findings are in tandem with the SCT which affirms that personal cognitive trait, which is EI in this study, is reciprocally associated with environmental abilities, which are oral communication skills in this study. More precisely, EI has a significant positive relationship with oral communication skills showing a t-value of 20.15 and $\beta$-value of 0.797 . In other words, this result elucidated that the Malaysian ESL students' oral communication skills were affected by their level of EI positively. Thus, the first objective of the present study was completely achieved at this stage by examining the relationship between EI and oral communication skills. This finding is in line with many studies (Afshar, \& Rahimi, 2014; 2016; Batool, 2013; Ebrahimi et al., 2018; Erigüç \& Köse, 2013; Fall et al., 2013; Lee \& Gu, 2013; Schutte et al., 2002). A study by Chang and $\mathrm{Hu}$ (2017). which supports the present study's findings, found significant positive associations between oral communication skills and EI among 272 elementary school directors in Taiwan. Like the present study, their study is quantitative in nature which gives this study a solid support. Another interesting study that supports the present study was Suhaimi et al. (2014) 
who proposed a framework linking significantly EI and interpersonal communication skills in the Malaysian context.

Furthermore, OCSs were significantly but negatively correlated with SLSA (t-value= 20.662; $\beta$ value $=-0.705)$. This result entails that when the level of second language speaking anxiety was high, their level of oral communication skills was low and vice versa. Thus, the second objective of the present study was fully attained at this stage by examining the relationship between oral communication skills and second language speaking anxiety. Numerous studies supported this outcome (Afshar \& Rahimi, 2014; Ahmed et al., 2017; Akbar et al., 2018; Alias et al., 2013; Alshahrani \& Alandal, 2015; Azarfam \& Baki, 2012; Çağatay, 2015; Debreli \& Demirkan, 2015; Doğan \& Tuncer, 2016; El-Sakka, 2016; Gaibani \& Elmenfi, 2016; Khoshsima et al., 2018; Liu \& Chen, 2015; Maisarah, 2019; Mukminin et al., 2015; Nijat et al., 2019; Ohata, 2005; Pappamihiel, 2002; Razak et al., 2017; Santos et al., 2017; Tercan \& Dikilitaş, 2015; Zhiping \& Paramasivam, 2013). In accordance with the present study's findings, Soomro et al. (2019) conducted a qualitative study on oral communication and second language anxiety among eight participants in Pakistan. The results showed strong association between the variables. In other words, their study indicated that second language anxiety is primarily caused by the deficiency of oral communication skills.

Lastly, the results of the third research objective indicated that 'oral communication skills' successfully mediated the association between 'EI' and 'second language speaking anxiety'. This finding is supported by SCT (Bandura, 1986). According to the aforementioned theory, environmental abilities are affected and generated from personal cognitive traits (i.e., EI) which in turn affect the performance and behaviour of individuals (i.e., second language speaking anxiety) (Bandura, 1986, 1997). Oral communication skills were proven to successfully mediate psychological and social variables (Carroll, Hill, Yorgason, Larson, \& Sandberg, 2013). Therefore, the third objective of the present study was achieved by determining the mediating role of oral communication skills between EI and second language speaking anxiety.

\section{IMPLICATIONS}

This section provides several theoretical and practical implications. Firstly, in the current study, the association of 'EI' with 'second language speaking anxiety' was investigated via the mediation of oral communication skills. Previous studies indicated that 'EI' is a significant predictor of various academic variables including academic achievement, mathematics, management, English language achievement, and French language achievement (Festus, 2012; McCleskey, 2014; Colomeischi \& Colomeischi, 2015; Musonda, 2017; Tariq et al., 2013; Yeigh et al., 2016). However, there was a shortage of studies regarding the relationship between 'EI' and 'second language speaking anxiety'. The current study indicated that EI is a significant predictor of second language speaking anxiety among Malaysian ESL students. These findings could be beneficial for ESL teachers and students. ESL teachers can raise the awareness of EI in their students in order to decrease their speaking anxiety. Moreover, this study contributed to SCT. SCT has been used in numerous research fields. However, more specifically, in ESL, the current research is first of its nature which employed SCT to examine the connection between 'EI' and 'second language speaking anxiety'. Thus, the current study has helped to enlarge the scope of SCT.

Secondly, rigorous literature review indicated that 'EI' was correlated with several kinds of language skills (Chang \& Hu, 2017; Kahraman, 2013; Marzuki et al., 2015; Schutte et al., 2002; Shao et al., 2013; Soomro et al., 2019; Suhaimi et al., 2014). However, limited research was conducted on the relationship between 'EI' and 'oral communication skills'. Also, 
Chang and $\mathrm{Hu}$ (2017) suggested that research ought to be conducted to find other associations between the two variables. Thus, the current study examined the roles of 'EI' in 'oral communication skills' for the sake of filling this gap in the body of literature. Findings of the current study disclosed that EI was substantially associated with 'oral communication skills'. These findings could be potentially beneficial for ESL teachers. Oral communication skills are environmental abilities which influence the performance of the learners (Bandura, 1986, 1997). Thus, ESL teachers can inculcate EI among their students in order to enhance their oral communication skills.

\section{LIMITATIONS}

The current study was quantitative in nature. It is recommended that there should be a study conducted via a qualitative or mixed-methods design to deeply understand all perspectives of the investigated phenomena. More particularly, future researchers ought to conduct interviews to explore the factors responsible for the relationship between the current study's variables.

\section{REFERENCES}

Afshar, H. S., \& Rahimi, M. (2014). The relationship among critical thinking, emotional intelligence, and speaking abilities of Iranian EFL learners. Procedia-Social and Behavioral Sciences, 136, 75-79.

Afshar, H. S., \& Rahimi, M. (2016). Reflective thinking, emotional intelligence, and speaking ability of EFL learners: Is there a relation?. Thinking Skills and Creativity, 19, 97-111.

Ahmed, N., Pathan, Z. H., \& Khan, F. S. (2017). Exploring the causes of english language speaking anxiety among postgraduate students of university of balochistan, pakistan. International Journal of English Linguistics, 7(2), 99.

Aida, Y. (1994). Examination of Horwitz and Cope's construct of foreign language anxiety: The case of students of Japanese. Modern Language Journal, 78(2), 155-67.

Akbar, A., Sofyan, D., \& Damayanti, I. (2018). FACTORS CAUSING FOREIGN LANGUAGE ANXIETY (FLA) IN SPEAKING. Journal of English Education and Teaching, 2(2), 46-57.

Alias, M., Sidhu, G. K., \& Fook, C. Y. (2013). Unemployed graduates' perceptions on their general communication skills at job interviews. Procedia-Social and Behavioural Sciences, 90, 324-333.

Al-Saqqaf, A. A. M. (2015). The relationship between oral communication strategy with language motivation and language anxiety among Yemeni postgraduates in Malaysia (Doctoral dissertation). Universiti Utara Malaysia, Kedah, Malaysia.

Alshahrani, M., \& Alandal, A. (2015). An investigation of anxiety among elementary school students towards foreign language learning. Studies in Literature and Language, 11(1), 29-40.

Amengual-Pizarro, M. (2018). Foreign language classroom anxiety among English for Specific Purposes (ESP) students. International Journal of English Studies, 18(2), 145-159.

AY, S. (2010). Young adolescent students' foreign language anxiety in relation to language skills at different levels. Journal of International Social Research, 3(11), 83-91.

Azarfam, A. Y., \& Baki, R. (2012). Exploring language anxiety regarding speaking skill in Iranian EFL learners in an academic site in Malaysia. International Journal of Applied Linguistics \& English Literature, 1(2), $153-162$.

Bandura, A. (1986). The explanatory and predictive scope of self-efficacy theory. Journal of Social and Clinical Psychology, 4(3), 359-373.

Bandura, A. (1997). Self-efficacy: The exercise of control. New York, NY: Freeman.

Bandura, A. (2001). Social cognitive theory: An agentic perspective. Annual review of psychology, 52(1), 1-26.

Bartlett, J. E. Kotrlik, J. W. \& Higgins, C. C. (2001). Organizational research: Determining appropriate sample size in survey research. Information Technology, Learning, and Performance Journal, 19(1), 43-50.

Batool, B. F. (2013). Emotional intelligence and effective leadership. Journal of business studies quarterly, 4(3), 84.

Boyatzis, R. E., \& Saatcioglu, A. (2008). A 20-year view of trying to develop emotional, social and cognitive intelligence competencies in graduate management education. Journal of management development, $27(1), 92-108$. 
Boyatzis, R. E., Goleman, D., \& Rhee, K. (2000). Clustering competence in emotional intelligence: Insights from the Emotional Competence Inventory (ECI). Handbook of emotional intelligence, 99(6), 343-362.

Çağatay, S. (2015). Examining EFL students' foreign language speaking anxiety: The case at a Turkish state university. Procedia-Social and Behavioral Sciences, 199, 648-656.

Carroll, S. J., Hill, E. J., Yorgason, J. B., Larson, J. H., \& Sandberg, J. G. (2013). Couple communication as a mediator between work-family conflict and marital satisfaction. Contemporary Family Therapy, 35(3), $530-545$.

Chalak, A. \& Kassaian, Z. (20 10). Motivation and attitudes of Iranian undergraduate EFL students towards learning English. GEM OnlineTM Journal of Language Studies. 10(2), 37-56.

Chang, C. P., \& Hu, C. W. (2017). Effect of communication competence on self-efficacy in Kaohsiung elementary school directors: Emotional intelligence as a moderator variable. Creative Education, 8(4), 549-563.

Cheng, Y. S. (2017). Development and preliminary validation of four brief measures of L2 language-skill-specific anxiety. System, 68, 15-25.

Cohen, J. (1988). Statistical power analysis for the behavioral sciences (2nd ed.). London: Lawrence Erlbaum Associates Publishers.

Colomeischi, A. A., \& Colomeischi, T. (2015). The students 'emotional life and their attitude toward mathematics learning. Procedia-Social and Behavioral Sciences, 180, 744-750.

Creswell, J. (2003). Research design: Qualitative, quantitative and mixed methods approaches (2nd Ed.). Thousand Oaks, CA: Sage.

Daud, N. S. M., Daud, N. M., \& Kassim, N. L. A. (2016). Second language writing anxiety: Cause or effect?. Malaysian journal of ELT research, 1(1), 19.

Debreli, E., \& Demirkan, S. (2015). Sources and levels of foreign language speaking anxiety of English as a foreign language university students with regard to language proficiency and gender. International Journal of English Language Education, 4(1), 49-62.

Dewaele, J. M., MacIntyre, P. D., Boudreau, C., \& Dewaele, L. (2016). Do girls have all the fun? Anxiety and enjoyment in the foreign language classroom. Theory and practice of second language acquisition, 2(1), 41-63.

Dewaele, J. M., Witney, J., Saito, K., \& Dewaele, L. (2018). Foreign language enjoyment and anxiety: The effect of teacher and learner variables. Language teaching research, 22(6), 676-697.

Doğan, Y., \& Tuncer, M. (2016). Examination of foreign language classroom anxiety and achievement in foreign language in Turkish university students in terms of various variables. Journal of Education and Training Studies, 4(5), 18-29.

Ebrahimi, M. R., Khoshsima, H., Zare-Behtash, E., \& Heydarnejad, T. (2018). Emotional Intelligence Enhancement Impacts on Developing Speaking Skill among EFL Learners: An Empirical Study. International Journal of Instruction, 11(4), 625-640.

El-Sakka, S. M. F. (2016). Self-Regulated Strategy Instruction for Developing Speaking Proficiency and Reducing Speaking Anxiety of Egyptian University Students. English Language Teaching, 9(12), 22-33.

Engelberg, E., \& Sjöberg, L. (2005). Emotional intelligence and interpersonal skills. International Handbook of Emotional Intelligence, 289-308.

Erigüç, G., \& Köse, S. D. (2013). Evaluation of emotional intelligence and communication skills of health care manager candidates: a structural equation modeling. International journal of business and social science, 4(13), 115-123.

Fall, L. T., Kelly, S., MacDonald, P., Primm, C., \& Holmes, W. (2013). Intercultural communication apprehension and emotional intelligence in higher education: Preparing business students for career success. Business Communication Quarterly, 76(4), 412-426.

Festus, A. B. (2012). The relationship between emotional intelligence and academic achievement of senior secondary school students in the Federal Capital Territory, Abuja. Journal of Education and Practice, $3(10), 13-19$.

Fornell, C., \& Larcker, D. F. (1981). Evaluating structural equation models with unobservable variables and measurement error. Journal of Marketing Research, 18(1), 39-50.

Gaibani, A., \& Elmenfi, F. (2016). Age as an Affective Factor in Influencing Public Speaking Anxiety of English Language Learners at Omar Al-Mukhtar University. Advances in Language and Literary Studies, 7(2), 179-182.

George, D., \& Mallery, P. (2016). IBM SPSS statistics 23 step by step: A simple guide and reference. New York, NY: Routledge.

Giorgi, G., \& Majer, V. (2009). Organizational Emotional Intelligence Questionnaire. Firenze: Giunti OS Organizzazioni Speciali.

Goleman, D. (1998). Working With Emotional Intelligence. London: Bloomsbury Publishing.

Goleman, D., Boyatzis, R. and McKee, A. (2002) Primal leadership: Realising the Power of Emotional Intelligence. Boston: Harvard Business School Press. 
Guvenc, G., Unver, V., Basak, T., Yuksel, C., Ayhan, H., Kok, G., ... \& Iyigun, E. (2016). Turkish senior nursing students' communication experience with English-speaking patients. Journal of Nursing Education, 55(2), 73-81.

Hair Jr., J. F., Black, W. C., Babin, B. J., Andersen, R. E., \& Tatham, R. L. (2010). Mutilvariate data analysis $\left(7^{\text {th }}\right.$ ed.). Upper Saddle River, NJ: Pearson Prentice Hall.

Hamat, A., \& Hassan, H. A. (2019). Use of Social Media for Informal Language Learning by Malaysian University Students. 3L: Language, Linguistics, Literature, 25(4), 68 - 83.

Hameed, W. U., Basheer, M. F., Iqbal, J., Anwar, A., \& Ahmad, H. K. (2018). Determinants of Firm's open innovation performance and the role of $\mathrm{R} \& \mathrm{D}$ department: an empirical evidence from Malaysian SME's. Journal of Global Entrepreneurship Research, 8(1), 29-49.

Hamzah, M. H. (2007). Language anxiety among first-year Malay students of the International Islamic College: An investigation of L2 skills, sources of anxiety, and L2 performance. Unpublished masters' thesis, International Islamic University Malaysia, Malaysia.

Haskin, J., Smith, M., \& Racine, M. (2003). Decreasing anxiety and frustration in the Spanish language classroom Published Masters' Thesis, Saint Xavier University \& IRI/Skylight, Chicago, Illinois.

Heng, C. S., Abdullah, A. N., \& Yusof, N. (2012). Investigating the construct of anxiety in relation to speaking skills among ESL tertiary learners. 3L: Language, Linguistics, Literature, 18(3), 155-166.

Henseler, J., Ringle, C. M., \& Sinkovics, R. R. (2009). The use of partial least squares path modeling in international marketing. New Challenges to International Marketing Advances in International Marketing, 20(1), 277-319.

Horwitz, E. K. (2016). Factor structure of the foreign language classroom anxiety scale: Comment on Park (2014). Psychological reports, 119(1), 71-76.

Horwitz, E. K., Horwitz, M., \& Cope, J. (1986). Foreign language classroom anxiety. Modern Language Journal, $70(1), 125-132$.

Hwang, G. J., Hsu, T. C., Lai, C. L., \& Hsueh, C. J. (2017). Interaction of problem-based gaming and learning anxiety in language students' English listening performance and progressive behavioral patterns. Computers \& Education, 106, 26-42.

Ilter, B. G. (2009). Effect of technology on motivation in EFL classrooms. Turkish online journal of distance education, 10(4), 136-158.

Khawaja, N. G., Chan, S., \& Stein, G. (2017). The Relationship Between Second Language Anxiety and International Nursing Students Stress. Journal of International Students, 7(3), 601-620.

Khoshsima, H., Sarani, A., \& Ganji, M. (2018). A Dynamic Intervention for Removing Learning Anxiety: A Field Experiment on Removing Psychological Barriers to Speaking. International Journal of Behavioral Sciences, 12(1), 25-31.

Lee, E. J. E. (2016). Reducing international graduate students' language anxiety through oral pronunciation corrections. System, 56, 78-95.

Lee, O. S., \& Gu, M. O. (2013). The relationship between emotional intelligence and communication skill, clinical competence \& clinical practice stress in nursing students. Journal of the korea Academia-Industrial cooperation Society, 14(6), 2749-2759.

Lian, L. H., \& Budin, M. (2014). Investigating the relationship between English language anxiety and the achievement of school based oral English test among Malaysian Form Four students. International Journal of Learning, Teaching and Educational Research, 2(1), 67-79.

Liu, H. J., \& Chen, C. W. (2015). A Comparative Study of Foreign Language Anxiety and Motivation of Academic-and Vocational-Track High School Students. English Language Teaching, 8(3), 193-204.

MacIntyre, P. D., \& Gardner, R. C. (1988). The measurement of anxiety and applications to second language learning: An annotated bibliography (Research Bulletin No.672). London, Canada: The University of Western Ontario, Department of Psychology.

Maisarah, M. (2019). Factors Causing Anxiety in Speaking English Experienced By The Students of Senior High School in Jombang. Jurnal Darussalam: Jurnal Pendidikan, Komunikasi dan Pemikiran Hukum Islam, 10(2), 232-243.

Marwan, A. (2016). Investigating students' foreign language anxiety. Malaysian Journal of ELT Research, 3(1), 19.

Marzuki, N. A., Mustaffa, C. S., \& Saad, Z. M. (2015). Emotional intelligence: Its relationship with communication and information technology skills. Asian Social Science, 11(15), 267-274.

McCleskey, J. (2014). Emotional intelligence and leadership: A review of the progress, controversy, and criticism. International Journal of Organizational Analysis, 22(1), 76-93.

Meganathan, P., Yap, N. T., Paramasivam, S., \& Jalaluddin, I. (2019). Incidental and Intentional Learning of Vocabulary among Young ESL Learners. 3L: Language, Linguistics, Literature, 25(4), 51 - 67.

Melchor-Couto, S. (2017). Foreign language anxiety levels in Second Life oral interaction. ReCALL, 29(1), 99119. 
Miskam, N. N., \& Saidalvi, A. (2019). Investigating English Language Speaking Anxiety among Malaysian Undergraduate Learners. Asian Social Science, 15(1), 1-7.

Morreale, S.P., Spitzberg, B. H., \& Barge, J. K. (Eds.). (2007). Human communication: Motivation, knowledge, and skills. (2nd Ed.). Belmont, CA: Thomson \& Wadsworth.

Mukminin, A., Masbirorotni, M., Noprival, N., Sutarno, S., Arif, N., \& Maimunah, M. (2015). EFL speaking anxiety among senior high school students and policy recommendations. Journal of Education and Learning, 9(3), 217-225.

Musonda, A. (2017). Algebraic competences and emotional intelligence of first year Bachelor of Science in Mathematics and Science Education students at the Copperbelt University in Zambia. Tuning Journal for Higher Education, 5(1), 171-195.

Nijat, N., Atifnigar, H., Chandran, K., Selvan, S. L. T., \& Subramonie, V. (2019). Psychological Factors that Affect English Speaking Performance among Malaysian Primary School Pupils. American International Journal of Education and Linguistics Research, 2(2), 64-76.

Ohata, K. (2005). Potential sources of anxiety for Japanese learners of English: Preliminary case interviews with five Japanese college students in the US. TESL-EJ, 9(3), 1-21.

Pappamihiel, N. E. (2002). English as a second language students and English language anxiety: Issues in the mainstream classroom. Research in the Teaching of English 36, 327-355.

Preacher, K. J., Rucker, D. D., \& Hayes, A. F. (2007). Addressing moderated mediation hypotheses: Theory, methods, and prescriptions. Multivariate Behavioral Research, 42(1), 185-227.

Rajab, A., Zakaria, W. Z. W., Rahman, H. A., Hosni, A. D., \& Hassani, S. (2012). Reading anxiety among second language learners. Procedia-Social and Behavioral Sciences, 66, 362-369.

Razak, N. A., Yassin, A. A., \& Maasum, T. N. R. B. T. (2017). Effect of Foreign Language Anxiety on Gender and Academic Achievement among Yemeni University EFL Students. English Language Teaching, 10(2), 73-85.

Santos, A., Gorter, D., \& Cenoz, J. (2017). Communicative anxiety in the second and third language. International Journal of Multilingualism, 14(1), 23-37.

Schutte, N. S., Malouff, J. M., Simunek, M., McKenley, J., \& Hollander, S. (2002). Characteristic emotional intelligence and emotional well-being. Cognition \& Emotion, 16(6), 769-785.

Serraj, S., \& Noordin, N. B. (2013). Relationship among Iranian EFL Students' Foreign Language Anxiety, Foreign Language Listening Anxiety and Their Listening Comprehension. English Language Teaching, $6(5), 1-12$.

Shao, K., Yu, W., \& Ji, Z. (2013). An exploration of Chinese EFL students' emotional intelligence and foreign language anxiety. The Modern Language Journal, 97(4), 917-929.

Shehzad, M. W., Lashari, S. A, Alghorbany, A., \& Lashari, T. A. (2019). Self-efficacy Sources and Reading Comprehension: The Mediating Role of Reading Self-efficacy Beliefs. 3L: Language, Linguistics, Literature, 25(3), $90-105$.

Soomro, M. A., Siming, I. A., Channa1, M. A., Shah, S. H. R., Naeem, N. \& Abbasi, A. M. (2019). An analysis of English oral communication apprehension and anxiety of engineering undergraduates in Pakistan. International Journal of English Linguistics, 9(2), 162-173.

Suhaimi, A. W., Marzuki, N. A., \& Mustaffa, C. S. (2014). The relationship between emotional intelligence and interpersonal communication skills in disaster management context: A proposed framework. ProcediaSocial and Behavioural Sciences, 155, 110-114.

Tariq, V. N., Qualter, P., Roberts, S., Appleby, Y., \& Barnes, L. (2013). Mathematical literacy in undergraduates: role of gender, emotional intelligence and emotional self-efficacy. International Journal of Mathematical Education in Science and Technology, 44(8), 1143-1159.

Teimouri, Y., Goetze, J., \& Plonsky, L. (2019). SECOND LANGUAGE ANXIETY AND ACHIEVEMENT: A META-ANALYSIS-ERRATUM. Studies in Second Language Acquisition, 41(2), 489-489.

Tercan, G., \& Dikilitaş, K. (2015). EFL students' speaking anxiety: a case from tertiary level students. ELT Research Journal, 4(1), 16-27.

Thompson, A. S., \& Khawaja, A. J. (2016). Foreign language anxiety in Turkey: The role of multilingualism. Journal of Multilingual and Multicultural Development, 37(2), 115-130.

Tsao, J. J., Tseng, W. T., \& Wang, C. (2017). The effects of writing anxiety and motivation on EFL college students' self-evaluative judgments of corrective feedback. Psychological Reports, 120(2), 219-241.

Ushioda, E., \& Dörnyei, Z. (2011). Teaching and researching: Motivation. Pearson Education.

Villalba, F., \& Luz, A. (2017). The effect of language anxiety in oral production in university students. Published Master's thesis, Icesi University, Colombia.

Yeigh, T., Woolcott, G., Donnelly, J., Whannell, R., Snow, M., \& Scott, A. (2016). Emotional literacy and pedagogical confidence in pre-service science and mathematics teachers. Australian Journal of Teacher Education, 41(6), 7. 
Young, D. J. (1991). Creating a low-anxiety classroom environment: What does language anxiety research suggest?. The Modern Language Journal, 75(4), 426-437.

Young, D. J. (1992). Language anxiety from the foreign language specialist's perspective: Interviews with Krashen, Omaggio Hadley, Terrell, and Rardin. Foreign Language Annals, 25(2), 157-172.

Zhiping, D., \& Paramasivam, S. (2013). Anxiety of speaking English in class among international students in a Malaysian university. International Journal of Education and Research, 1(11), 1-16. 